\title{
Teacher as Role Model: The South African Position on the Character of the Teacher
}

\author{
Okeke, $\mathrm{ClO}$ \\ Faculty of Education, University of Fort Hare \\ cokeke@ufh.ac.za \\ Drake, ML \\ Faculty of Education, University of Fort Hare \\ mdrake@ufh.ac.za
}

\section{Doi:10.5901/mjss.2014.v5n20p1728}

\section{Abstract}

This paper interrogates the South African policy document on minimum requirements for teacher education qualifications regarding character education for student teachers. Reflecting on teachers' character through the medium of the values education initiative in South Africa, this paper seeks to understand whether any legal and pedagogical framework exist in the recent teacher training document to support the teaching and learning of character education by students in training institutions. Character education encompasses the multiple layers of influences that enable the individuals to become morally responsible and self-disciplined citizens. The paper presents evidence from international literature to highlight the imperativeness of character education for initial teacher education as germane for the production of the right calibre of quality teachers for the South African schools. The paper suggests the need for a proper mandate and pedagogical framework on character education for teacher training institutions. Some curricula issues involved in character education are presented. Noting that the public holds schools and teachers accountable for societal demeanour, the paper concludes that policy-informed, well structured character education would culminate in the raising of the right calibre of teachers that may be responsive to demanding societal and pedagogical needs of South African education.

Keywords: character education, values education, teacher role-models, education policy, South African education

\section{Introduction}

It is an age-long saying that teachers are role models. But perhaps the hard question begging to be asked right now is: what are teachers modelling? The importance of teachers as role models in the socialization of the child is well documented in teacher education literature (Sava, 2002; Ozel, 2007; Lumpkin, 2008). Teachers serve as role models through how they perform their duties and by the manner they conduct themselves. Literature on the impact of teacher attitudes, behaviours and personality on students' overall academic, social and personality wellbeing is significant (Harden \& Crosby, 2000; Narvaez \& Lapsley, 2008; Seyyed-Hassan, Roghayyeh \& Mustafa, 2008; Kagoda, 2011). There appears to be universal agreement that students learn from their teachers in more ways than one; they learn from the way teachers dress, speak and behave.

In spite of this understanding, teacher education reform initiatives in South Africa appear to focus more on curriculum reforms and on various aspects of curricular specifics including subject competences. The primary focus within South African education policy on the character of the teacher or teacher role-modelling appears to be through the medium of values education. The values education initiative began in 2000 , with the design and implementation of the Manifesto on Values, Education and Democracy (Department of Education) released in 2001. Within this values Manifesto, sixteen educational strategies were announced, which were seen as the vehicles in which these values were to be realised and enacted in schools. The second of these strategies is role-modelling, where it is described how one of the most powerful ways children and young adults acquire values is to see individuals they admire and respect exemplify those values in their own being and conduct. The question of leadership generally, and in the educational sphere particularly, is therefore of vital importance (Nelson Mandela in Department of Education, 2001a, p. 19). The values initiative emphasises that teachers and administrators must be leaders, and set the example since children learn by example, consciously and unconsciously.

Yet, the primary focus of the newly released Minimum Requirement for Teacher Education Qualifications (DHET, 
2011) appears to relate to how to prepare the teacher to effectively deliver a particular content knowledge and on how to ensure that he/she is available to perform this pedagogical role. Similarly, teacher education programmes also reflect this demand. As a result, there is usually an unwitting neglect of the importance of character education for trainee teachers as germane to the quality of values-education that are given back to the society through the students. Sadly, the quest for more bodies to fill the vacant positions in schools has resulted in teacher training institutes being flooded by all categories of persons with both natural and superficial interest in teaching (Stoll \& Beller, 1998; Robinson, 2003; Thakrar, Zinn \& Wolfenden, 2009). This paper argues in favour of a well-designed and specialised character education for initial teacher education programmes in South Africa. It is hoped that this contribution will provide insights to teacher education policymakers on the imperativeness of a well-structured character education programme for teachers who are continuously being looked upon by society as role models to the younger generation.

\title{
2. Theoretical Construct
}

This paper derives from the microsystem theory. The microsystem layer of the child's ecological development represents the layer that is closest to the child, and includes the structures that the child has direct contact with (Beckett \& Taylor, 2010). This includes people and institutions the child interacts with within the environment. Examples include the immediate family members, schools and teachers. The striking importance of this layer, also known as the proximal processes (Gabarino, 1992; Donald, Lazarus \& Lolwana, 1997; Beckett \& Taylor, 2010) is that as the interactions proceed, the type of influence they will exact on the child's development will depend to a large extent on the content and structure of the microsystem. With respect to the teacher, it would seem appropriate to suggest that what the teacher offers the growing child depends largely on what is available to him or her. And where it borders on moral values by which the components of character resonate, the teacher can only give that in his or her possession. This analysis challenges providers of teacher education to ensure that the individual teacher is adequately equipped academically and morally.

\section{Policy Developments Regarding Teachers' Character}

Responsibility for change and transformation in the education sphere lies primarily with the teacher. Jansen (2001) describes powerful images of teachers after apartheid, including the teacher as 'liberator', 'facilitator', and 'performer'. Together with these images, education policy reform that encourages more active, reflective and participant classrooms places much emphasis on the role of the teacher in post-apartheid South Africa. However, for many teachers, their training and experience lies within the country's apartheid history, where educators were described as "obedient civil servant[s] that executed the well-defined instructional tasks per an official syllabus and a "moderated" examination" (Jansen, 2001, p. 243). This mismatch in history, training and new policy expectations creates a tense and demanding environment for educators. Teachers are key to the success of curriculum reform (Bantwini, 2010). However, these policy reforms have only been partially successful in schools, because issues like traditional, teacher-dominated classrooms, authoritarian head teachers, and the use of corporal punishment and sexual harassment make achieving quality education challenging (Mncube \& Harber, 2010). These inhibitors are related to the role of the teacher and also alert to the vital need for character development of trainee teachers:

\begin{abstract}
"It is fashionable to think of education in terms of the "development of competencies", but there are limitations to this view. Nazi leaders were not in general lacking in competences. High degrees of competence are compatible with moral degeneracy. Most teacher-education programmes focus [too] sharply on the development of competence and not enough on professional commitment" (Morrow as cited in Department of Education, 2001a, p. 30).
\end{abstract}

Yet, the values Manifesto also highlights the current issues that impact severely on schools and education in South Africa. The Manifesto gives way to underlying assumptions that teachers, parents, officials or students have not succeeded in making the values enshrined in the Constitution of South Africa part of 'the new' in the post-1994 South Africa. The reason for this is aligned with issues of absenteeism of teachers, absenteeism of students, the problems with providing a safe and secure school environment, verbal, physical and sexual abuse perpetrated by both educators and students, and a lack of dignity when it comes to what teachers do and how they do it, as well as, the teaching and learning environment being contained in impossible conditions, which many times, are entirely beyond the control of educators (Department of Education, 2001a, p. 15). However, it can also be argued that due to the extreme nature of schools in South Africa, the need for teachers with strong moral and ethical foundations are crucial to educational 
success.

Within values policy, teachers are also expected to play "a community, citizenship and pastoral role", to practise and promote "a critical, committed and ethical attitude towards developing a sense of respect and responsibility towards others", "uphold the Constitution and promote democratic values and practice in schools and society", "demonstrate an ability to develop a supportive and empowering environment for the learner" and "develop supportive relations with parents and other key persons and organisations based in a critical understanding of community and environmental development issues" (Department of Education, 2001a, p. 59).

The Code of Conduct of the South African Council of Educators (SACE), a statutory body to which educators and newly trained educators are expected to gain membership, is even more specific. It commits teachers to "acknowledge the noble calling of their profession to educate and train the learners of their country", to "acknowledge that the attitude, dedication, self-discipline, ideals, training and conduct of the teaching profession determine the quality of education", to "acknowledge, uphold and promote basic human rights", to "commit themselves to do all within their power, in the exercising of their professional duties, to act in accordance with the ideals of their profession", and to "act in a proper and becoming way such that their behaviour does not bring the teaching profession into disrepute" (as cited in Department of Education, 2001a, p. 60). Therefore, these policy statements appear to drive the need for character education for South African teachers. Teachers appear to have a special place in the internalising process of the ten fundamental values of the South African Constitution themselves, and to act as role models for the learners they interact with on a daily basis (Department of Education, 2001a, p. 32).

The National Qualifications Framework Act 67 of 2008 policy on the Minimum Requirements for Teacher Education Qualifications, a few years on from the values initiatives, emerged to address most of the challenges facing South Africa's (teacher) education. It seemed to fall short when it comes to addressing the ethical and moral core of the teacher. Some of the acknowledged challenges in this policy document resonate with the challenges mentioned before, such as: the lingering legacies of Apartheid; poor teacher education quality; persistent presence of teachers with poor or limited conceptual knowledge; lack of physical resources in some schools; poor support for pupils at home; insufficient teacher support; and until the emergence of Act 67 of 2008, absence of formal legislation on effective teacher education (DoE, 2000; Robinson, 2003; DoE, 2007b; CHE, 2010; DHET, 2011). Yet, the values education initiative in 2001 took into consideration the role of the teacher by referring to them as "custodians of our value systems in the school environment" (Zuma, Department of Education, 2001b).

Policy can describe the ideal teacher with clarity and precision, but does not see the real teacher and the cultural and material constraints imposed by classroom reality clearly enough to understand what must be involved in achieving this ideal (Harley, Brasa, Bertram, Mattson, \& Pillay, 2000, p. 302). The teacher-as-person (Jessop \& Penny, 1998) is a key consideration for the effective accpetance of policy in South African education. A shift from theorising about educational change to an arena of teacher beliefs and history is necessary. The recovery of the teacher vision becomes critical (p. 402). Issues of declining teacher character appears to be an unvoiced concern of many South Africans, and literature also appears scanty with regards to the imperativeness of character education for trainee teachers and teacher educators. Notwithstanding, if education is aimed to change society then teacher education alongside the teacher educators would have to be fundamentally changed; such change would have to be total. As teachers involved in teacher education, it is understood that teacher education as a process leading to the acquisition of two forms of character: performance character; and, moral character.

A genuine combination as well as evidenced display of these two elements of character in a person who has received training to teach, makes him or her ideal for the job, Teacher. For the avoidance of doubt, performance character, refers to certain dispositions including behavioural, emotional and cognitive (Davidson, 2012) that are mostly acquired through some prescribed training. Such training is required to enable an individual achieve such values and/or skills as ambition, critical thinking, diligence, determination, perseverance, positive attitude, work ethic, resilience, selfdiscipline and self-direction (Davidson, 2010). It must be noted that at the heart of performance character is what Davidson and Lickona (2007, p. 2) refer to as "mastery orientation". Such habits are required in human actors for them to achieve human excellence in such performance environments as the school and at the workplace. Here it is noted the emphasis on the importance of teachers as role-models in the values initiative appear rather superficial in light of "mastery orientation" referred to by Davidson and Lickona.

Moral character on the other hand, encapsulates all dispositions that are required for ethical functioning. It comprises such qualities as honesty, trust, respect, fairness, and responsibility (Stoll \& Beller, 1998; Lumpkin, 2008). Other components of moral character include differentiating right from wrong, sense of decency, decorum, reasoning, sincerity, humility, self-control, and sense of humour. Put together, these are referred to as moral principles or virtues, and education would best serve South African society when teachers teach and model these principles, while assisting 
their students to internalise and practise such moral virtues and values. With the above explanations in mind, it is safe to say that while the National Qualifications Framework Act 67 of 2008 policy on the Minimum Requirement for Teacher Education Qualifications emphasised performance character, it was unintentionally silent on the issue of moral character. The values education initiative, as the vehicle to address teacher role-modelling and character, is also less than convincing on the importance and need of moral character in South African teachers. This argument is tenable for three reasons. The first reason derives from how the new policy-document responded to the issues and challenges raised in the research and in the Higher Education Quality Committee (HEQC) reviews. For instance, unlike previous documents, e.g. the Norms and Standards in Education, NSE (2000), the new policy:

describes clear and specific requirements for the development of learning programmes and guidelines for practical and WIL structures; encourages teacher educators to become engaged with curriculum design, policy implementation and research; requires all teacher education programmes to address the critical challenges facing education in South Africa today; it requires new programmes to incorporate situational and contextual elements such that would assist teachers in developing competences that enable them to deal with diversity and transformation; and, the new policy-document retains the roles of a teacher described in the NSE 2000, but emphasises that the roles must be interpreted as functions carried out by the collective of teachers in a specific school (DHET, 2011, p. 6 \& 7).

No mention was made in the new policy-document on how to impact on the questionable character of the $21^{\text {st }}$ century South African teacher. The second reason for the position of this paper derives from the principles underpinning the design of the programmes leading to the teacher education qualifications. The recent policy-document notes that "teaching is a complex activity that is premised upon the acquisition, integration and application of different types of knowledge practises or learning" (DHET, 2011, p. 7). The document then typifies the components of learning that are linked with the acquisition, integration and application of knowledge to include the following: "disciplinary learning; pedagogical learning; practical learning; fundamental learning; and, situational learning (DHET, 2011, p. 8). While space does not allow for any detailed discussion on the above components, it is important to note that none of them mentioned anything on how the teacher character could be improved. Yet, the importance of character education resonates through the fact that "teachers are among individuals who spend numerous hours with students and can have an influential impact on the shaping of the students' good manner" (Seyyed-Hassan et al., 2008, p. 106).

A final reason for the position of this paper derives from the eleven (11) minimum set of basic competences required of the newly qualified South African teacher. These basic competences are well-documented in the Appendix C of the new policy-document. Although mention is made of "positive work ethic, display appropriate values and conduct themselves in a manner that befits, enhances and develops the teaching profession" (DHET, 2011, p. 53) it would be wrong to suggest that such requirements encapsulate all of 'moral character'. In addition, there is no evidence in neither the principles underpinning the design of teacher education programmes nor was there any evidence in the components of learning that are linked with the acquisition, integration and application of knowledge to suggest implicitly or explicitly that moral character education is part of the new policy-document.

A policy framework on moral character education for initial teacher education is therefore necessary as discussions are on-going on how to make South Africa's teachers better responsive to the needs of the South African society. This necessity is informed by the fact that "unless character development is directly addressed, the moral maturation process will not likely occur" (Lumpkin, 2008, p. 46). This paper argues for a crucial need for moral character education for initial teacher education.

\section{Explaining Moral Character Education}

We have noted the two components of character: performance and moral. Overall, character refers to the totality of continuously developing moral and ethical qualities, which individuals demonstrate as they live their everyday lives (Berkowitz \& Bier, 2004; U.S. DoE, 2007). Such qualities may be represented by the individuals through their personal, social as well as civic values, or through the combination of all of the three qualities. Character according to Lumpkin (2008, p. 45) "encompasses being good and doing right while behaving unethically is the antithesis of displaying character". In explaining character education, attention is paid to the influence that the multiple layers of the families, schools, teachers and other social institutions exact on the individuals including children and adults (Berkowitz \& Bier, 2004). The idea of character education within the context of teacher education reminds us of the imperativeness to empower teachers through a well-organised training programme aimed at equipping them well enough with the ideals of character. 
Character education therefore is a consciously engaged process by which teachers attempt to empower their pupils with the right moral virtues that enable them to live virtuously within the society. Such education emphasises the idea that teaching character is teaching the whole individual (Berkowitz \& Bier, 2004) in such a conscious manner to enable him/her to live a positively transformed life. It must be noted that character education encompasses very specific and direct approach to teaching moral and values education with a target on specific forms of values and behaviour (Hunter, 2000). As part of a planned curriculum, character education then becomes a variety of deliberate attempts through our teachings that enable children to understand, appreciate, and care about as well as act upon the established core ethical and citizenship values.

Within the context of initial teacher education programme in South Africa, character education when introduced and fully embraced, becomes a process that allows for the development of the whole individual. Such process would be aimed to equip the individual with the moral ingredients of civil, democratic, social and emotional values that enable the individual to appreciate his/her own worldview while acknowledging and respecting the diverse worldview of others. Emphasising the importance of character education Lickona (2004, p. 30) concludes that

character education is a good thing, an essential thing for us to do. Focusing on character in our families, schools, and communities will make a difference...for those involved. If the effort becomes widespread enough, it will make a difference for our whole country and perhaps, to the extent that we become a better people.

\section{Justifications for Moral Character Education as Part of Teacher Education}

Teaching is a unique and complex profession. Unlike other professions, teaching is a unique job that requires the teacher to act in a certain manner. Anyone who opts for the teaching profession engages in a lifelong process that demands him or her to behave in a certain way. The job of the teacher is to tell the truth and to behave uprightly at all times. For that reason, the person who wants to be a teacher has to be equipped with the necessary ingredients to assist him/her to live exemplary and in a way the society expects teachers to behave. The following therefore offer justifications for a wellstructured, policy-informed character education to be part of the programmes for initial teacher education.

\subsection{As a prerequisite for professional competence}

Societies the world over expect that teachers behave and act in a certain way. It is conventional wisdom that when one who is known to be a teacher behaves in a manner that is deemed irresponsible, he/she is repulsed by members of the immediate society. The perceived roles of teachers in the South African society require that they teach and model character. Lumpkin $(2008$, p. 49) argues that "teachers with character serve as role models for telling the truth, respecting others, accepting and fulfilling responsibilities, playing fair, earning and returning trust, and living a moral life". Lumpkin further argues that when teachers are in possession of character, they are able to teach their students how to engage in moral-reasoning process that will assist them to make morally-principled decisions about their lives. It is therefore necessary to make character education part of the requirements for teaching. Teachers that can achieve character in their pupils are those who have been equipped to teach and demonstrate the importance of character. We cannot argue the fact that our society requires teachers who are well-behaved; many decades past, this element was part of the inherent quality of the teacher. Perhaps, research is imperative in this regard to establish whether the contemporary teacher still sees him/herself as one whom society would constantly expect to behave morally.

\subsection{The proximal teacher-child relationships}

It is increasingly obvious that teachers are more and steadily becoming a primary agent of the socialisation process that most children encounter daily. Studies have shown that in some instances teachers appear to be the only socially and emotionally balanced (Boud, 1990; Beckett \& Taylor, 2010; Davidson, 2010); materially, as well as spiritually fit and healthy (Gough, 1998; Davidson \& Lickona, 2007) adults that some children encounter all day long. Moreover, the everincreasing responsibilities of the teachers make imperative the formal teaching of character education to the becoming teacher. For instance, in the past, teachers were not assigned such responsibilities as mentors, therapists, parentsubstitute, counsellor, and so on. Today however, the expectations from both the parents and society at large appear to put the teacher at the centre of these responsibilities. Some teachers may argue as personal experiences have shown that they do not want their pupils or anyone else to see them as role models. However, Harden and Crosby (2000, p. 10) argue that whether teachers want to be seen as role models or not, "it is difficult for learners not to be influenced by the 
living example set before them". The implication of Harden's and Crosby's position is that teacher education must be equipped to enable the production of the right calibre of teachers who would proudly serve as role models for the pupils.

\subsection{Social upheavals in contemporary families}

South African families, as in other countries, experience social disturbances. One such social upheaval is the ravaging effect of HIVIAIDS (Posel, Kahn \& Walke, 2007; Dworkin, Colvin, Hatcher \& Peacock, 2012), which has resulted in the emergence of child-headed homes and other dislocations within affected families. Other developments within the families that challenge the general wellbeing of the growing child include the increasing incidences of broken homes, increasing cases of child-parent resulting from teenage pregnancies, increasing cases of one-parent families, among others. Studies (Hunter, 2000; Lowe, 2008) have shown that children raised within such social circumstances constantly experience both emotional and behavioural imbalances in most instances. In the absence of a matured and responsible adult within their immediate families, teachers may become the substitute-parent and as such are required to be well-prepared for such arduous tasks.

\subsection{The social milieu within the larger society}

These are challenging times for parents, teachers, the government and society at large. The situation within society is without doubt, rife with problems. We listen to and read from the news many instances of violence against children and women. It is reasonable to say that government can potentially provide everything but character. The responsibility for character training rests naturally on both parents and teachers. However, the social upheavals in contemporary families as shown above, weakens the strength of most families to deliver this responsibility making the position of the teacher increasingly important. Lumpkin (2008, p. 49) argues that in most instances, "society is best served when teachers teach and model and students develop character and moral virtues". This is by no means prescriptive, however, it is suggested that with concerted efforts through some formal learning, it is possible that society may become better.

\subsection{Societal expectations on teachers as the custodians of wisdom}

Personal experiences have shown that members of the society still place their trust in the teachers' ability to live exemplary life. Teachers are expected to always be of good character because most "parents as well as the general public expect educators to teach character and virtues that can help shape and mould young people into contributing members of society" (Lumpkin, 2008, p. 47). Further empirical studies are required to find out whether families still believe in the ability of the teacher to assist in managing the recalcitrant behaviour of a particular child. Notwithstanding, given the fact that this expectation of the teacher as the custodian of wisdom and as disciplinarian still persists, it is therefore important to equip the teacher ready and able to perform such role whenever necessary to do so.

\subsection{The perceived depravity within teacher education}

Years ago, it was easy to identify a teacher simply because there was conventional wisdom in the saying: 'by their fruits we shall know them'. Back then, teachers were easily identified by the manner of their dressing or appearance and sense of decency or general decorum. Teachers were also identified by their level of comportment both in private and in public places. It was very easy to identify a teacher simply by his/her spirit of perseverance in all aspects of public and private lives. Most importantly, individuals wanting to take up teaching were strictly scrutinised in the first instance; for not everyone was called to teach. Such individuals were then accorded the right (qualified teachers status) to teach others after a long period of prescribed training, and having been found fit in terms of both the performance and moral character.

Today, the only prerequisite for admission into the teacher training institute is academic credentials, just as the only requirement to take up job as a teacher is a teaching qualification. However, the responsibilities of the teacher are considerable; they require more than a mere academic qualification. An effective school requires more than just having many teachers with the approved teaching and academic qualifications. Moreover, when parents seek schools for their children, they want to see beyond the qualifications of the teacher. Regarding the compulsory school experience component of current teacher qualifications, complaints are raised by teachers in the host schools on the character of some of the trainee teachers in their schools. Experiences have also shown that given the option, some of the host schools would opt out of the work-integrated partnership in many instances for reason of declining character. Evidence suggests that the greater majority of students who are currently undertaking training in most teacher training institutes 
have inappropriate character. Cases of students' misbehaviours during some of the examinable tasks including written essays, class tests, semester examinations as well as research projects suggest that the above justifications for a policyinformed character education remain a good option. This last issue also presents a character-based research agenda aimed to evaluate students' voices in this regard.

\section{Curriculum Issues for Character Education}

Narvaez and Lapsley (2008) argue that because there is no guarantee that students will experience positive moral formation outside of school, the task of preparing adept individuals requires a more intentional programmatic instructional focus. This suggestion then raises some pertinent questions about the teaching of character education to the becoming South African teachers: What makes for character education studies and at what level should it be taught? Who should teach it and are there additional training needs for that matter? Should character education be mainstreamed within existing modules or should it be a standalone course for teacher education? What about participation from the community: should school principals, teachers, parents and the larger community be involved in deciding what constitutes the content of such education? Should character education be made mandatory for all those who intend to teach? Will there be need for legislation on character education, and what should such legislation say?

Of course no change can happen without any resistance. To start with, acknowledgement must be given to what may constitute the unvoiced feeling of some critics of character education. For instance, critics may argue that there is,

little room in the school curriculum to educate for moral education. Many will say that moral education is the responsibility of parents together with faith communities and that in any case in a multicultural society there is no agreed way to determine what is good and bad character (Arthur \& Revell, 2005, p. 5).

While the above argument may be plausible, the justifications for character education as part of teacher education are overwhelming. Perhaps it is also pertinent to acknowledge as experience has shown, the fact that teachers appear to be repulsive to issues of add-ons to already choked daily official schedule. While it is safe to say that the demands for character education in schools should not be classified as additional burden, teachers should in fact see themselves as performing "parental function implicit and constitutive of the teacher in loco parentis" (Arthur \& Revell, 2005, p. 5), which has hitherto been abandoned. Let us try to provide some explanations to the questions raised above.

\subsection{What makes for moral character education studies; what level should it be taught?}

A well-structured teacher education for moral formation would contain ethical sensitivity, which will include learning to read and express emotions; caring by connecting to others; learning to work with groups and individual differences; taking the perspectives of others; and controlling social bias. Ethical judgement that may include learning to develop general reasoning skills; understanding ethical problems; identifying judgement criteria; reflecting on the process and outcomes; planning to implement decisions; and developing optimism. Ethical motivation, which will include learning about respecting others; developing conscience; acting responsibly; helping others; making peace and cooperating; valuing social structures; and developing ethical identity and integrity. Ethical action, which will include learning about communicating well; resolving conflicts and problems; taking initiatives as a leader; developing courage; developing perseverance; and working hard (Narvaez, 2001).

Although the above content-areas have been described by Narvaez (2008) as the integrative ethical education process model, how this will proceed within the South African context remains an issue for the curriculum experts, teachers and legislators. What is important is that the learning of such behavioural skills should form part of students' continuous learning programmes while still on the teacher education programme. Strategies should however, vary according to the level or year of programmes.

\subsection{Who should teach it: Are there additional training needs for that matter?}

Every teacher educator should be involved in the teaching of moral character and should be working in tandem with other professional colleagues. In-service programmes and teacher professional development workshops specifically designed should be mounted in support of the professional needs for all those involved in the teaching of moral character education. 


\subsection{Should it be mainstreamed within existing modules or be a standalone?}

One problem with mainstreaming important skills within existing programmes for professional development is that issues are often taken-for-granted. For that reason the suggestion is that it should be designed as a standalone with aspects of formative, summative and/evaluative tasks for students. It should be allocated its own space on the official school timetable and specific people should be held accountable.

\subsection{What would be the roles of the community?}

Community in this paper is perceived to include the following stakeholders: school principals, teachers, parents, and, other members of the larger community. Every member of the community should render a voice on what should constitute moral character that is necessarily partly informed by the shared values and norms of a given community. Therefore the voices of various members of the community should and must be heard about what may constitute the content of such education. However, such community approach has to be informed by concerted community-based character-driven research.

\subsection{Should character education be made mandatory for all those who intend to teach?}

Character education for moral formation is as important as academic certification. This is because targeting the intellect while neglecting the moral may arguably lead to a very dangerous transmogrification of the individual into a societal menace. A well-educated irresponsible person is a danger to that society. Character education that targets moral formation has been noted in research to have encouraged enabling classrooms in which students are ready to learn, while teachers appear to perform their works within such classrooms with little or no stress (Boud, 1990; Friedman, 1995; Bebeau et al., 1999; Narvaez, 2008). It is therefore necessary to make character education mandatory for all categories of students in teacher education institutes.

\subsection{Is there any need for legislation on character education?}

This paper argues for a definite need for legislation on character education. Various existing legislations that impact teacher education; students and teachers rights and responsibilities; and other education regulations suggest the imperativeness of some form of legislation in order to establish some clear guidelines. If the Constitutional values on South Africa are to be truly realised in schools and classrooms, the first step towards this ideal is a mandate for legislation on character education.

\section{Implications for Research}

The issue of moral character is a very sensitive one. The suggestion here is that actions toward its formal introduction and teaching at any level of schooling must be fully backed by research-based evidence. At this preliminary stage, the following may be necessary: A community-based research to establish various voices of the community as a whole: the community's moral and values concerns; the roles community expects teachers to play with regards to education of children and teacher conduct; and the changes the community members may expect to see education bring in terms of the behaviours of its children.

Research may be required to establish what members of the community may want character education to address and how it should be addressed. Research is needed to establish the views and knowledge held by the classroom teachers and other teaching professionals on character education for moral formation. Evidence in this area is important as it will assist in decision and policy-making on professional development of the teachers in South Africa. Perhaps, research is imperative in order to establish whether the contemporary South African teacher still sees him/herself as one whom society would constantly expect to behave better, and as a custodian of wisdom and South African values.

Research is also required to establish whether members of the society still place their trust in the teachers' ability to positively change behaviour. Lastly, research may also be required to evaluate all categories of students' voices in order to ensure that a democratised approach to character education will be put in place. 


\section{Concluding Remarks}

The issues raised in this paper are no idle ones. What may assist to improve the social and ethical demeanour of the teacher appears to be paramount. Teacher education is designed to produce a unique type of person; one in whom the intellectual and character formation of the child is basically placed. A good teacher is more than just completing approved programme of study and obtaining academic qualifications. The aim of teacher education is not just to produce persons to fill existing teaching positions in the classrooms. It also includes the training of persons who would assist children in a formal setting to become smarter and of good behaviour. Such children require moral character in order to behave in an ethically acceptable manner and to succeed in life. For teachers to succeed in such laborious tasks they require to learn some prescribed skills designed to enrich their abilities to deliver. The public holds schools and teachers accountable for societal demeanour. It is therefore thought that a policy-informed, well-structured character education would culminate in the raising of the right calibre of teachers that may be responsive to societal needs. Individual researchers, research institutes, academic institutions, non-governmental organs, and relevant government departments are therefore invited to this clarion call.

\section{References}

Arthur, J., \& Revell, L. (2005). Character formation in schools and the education of teachers. Canterbury: Christ Church University College.

Bantwini, B. (2010). How teachers perceive the new curriculum reform: Lessons from a school district in the Eastern Cape province, South Africa. International Journal of Educational Development, 30(1), 83-90. Retrieved August 18, 2011, from http://www.sciencedirect.com.ezproxy.auckland.ac.nz/science/article/pii/S0738059309000753

Bebeau, M. Rest, J. R., \& Narvaez, D. (1999). Beyond the promise: A framework for research in moral education. Educational researcher, 28(4): $18-26$.

Beckett, C., \& Taylor, H. (2010). Human growth and development. 2nd edition. London: Sage.

Berkowitz, M. W., \& Bier, M. C. (2004). Research-based character education. The Annals of the American Academy of Political and Social Science, 591(1): $72-85$.

Boud, D. (1990). Assessment and the promotion of academic values. Studies in Higher Education, 15(1): 101 - 111.

CHE (2010). National Review of Teacher Education Qualifications. Pretoria: Higher Education Quality Committee.

Davidson, M. (2010). Developing performance character and moral character in youth. Chattanooga: National Center for Youth Issues.

Davidson, M., \& Lickona. T. (2007). Smart and good: Integrating performance character and moral character in schools. Independence School, 2 - 7 .

Department of Education. (2001a). Manifesto on values, education and democracy. Retrieved February 28, 2008, from http://www.info.gov.za/view/DownloadFileAction?id=70295

Department of Education. (2001b). Saamtrek conference report: Values, education and democracy in the 21st century. Retrieved April 5 , 2008, from http://www.education.gov.za/dynamic/dynamic.aspx?pageid=329\&catid=10\&category=Reports\&legtype=null

DHET (2011). National Qualification Framework Act 67 of 2008 Policy on the Minimum Requirements for Teacher Education Qualifications. Government Gazette No. 34467, Vol. 553. Pretoria: DHET.

DoE (2000). Norms and Standards for Educators. Pretoria: Department of Education.

DoE (2007b). National Policy Framework for Teacher Education and Development. Pretoria: Department of Education.

Donald, D., Lazarus, S., \& Lolwana, P. (1997). Educational psychology in social context. New York: Oxford University Press.

Dworkin, S. L., Colvin, C., Hatcher, A., \& Peacock, D (2012). Men's perceptions of women's rights and changing gender relations in South Africa: Lessons for working with men and boys in HIV and anti-violence programs. Gender and Society, 26(1): 97 - 120.

Friedman, I. A. (1995). Student behaviour patterns contributing to teacher burnout. Journal of Educational Research, 88(5): 281 - 290.

Gabarino, J. (1992). Children and families in the social environment. New York: Aldine de Gruyter.

Gough, R. W. (1998). A practical strategy for emphasising character development in sport and physical education. Journal of Physical Education, Recreation \& Dance, 69(2): $18-23$.

Harden, R. M., \& Crosby, J. R. (2000). The good teacher is more than a lecturer: The twelve roles of the teacher. Medical Teacher, 24(4): $334-347$.

Harley, K., Brasa, F., Bertram, C., Mattson, E., \& Pillay, S. (2000). "The real and the ideal": Teacher roles and competences in South African policy and practice. International Journal of Educational Development, 20(2000), 287-304. Retrieved December 12, 2010, from http://www.sciencedirect.com.ezproxy.auckland.ac.nz/science/article/pii/S0738059399000796

Hunter, J. D. (2000). The death of character: Moral education in an age without good or evil. New York: Basic Books.

Jansen, J. (2001). Image-ining teachers: Policy images and teacher identity in South African classrooms. South African Journal of Education, 21(4), 242-246. Retrieved July 6, 2011, from http://137.215.9.22/bitstream/handle/2263/876/Jansen\%20 (2001)e.pdf?sequence $=2$

Jessop, T., \& Penny, A. (1998). A study of teacher voice and vision in the narratives of rural South African and Gambian primary school teachers. International Journal of Educational Development, 18(5), 393-403. Retrieved July 10, 2011, from http://www. 
sciencedirect.com.ezproxy.auckland.ac.nz/science/article/pii/S073805939800039X

Kagoda, A. M. (2011). Role models and life histories of teacher trainers as tools for effective teacher education: A case for geography teacher trainers in Uganda. Mediterranean Journal of Social Sciences, 2(7): 91 - 100.

Lickona, T. (2004). Character matters. New York: Simon \& Schuster.

Lowe, J. (2008). A Cultural approach to conducting HIVIAIDS and Hepatitis C virus education among Native American adolescents. The Journal of School Nursing, 24(4): 229-238.

Lumpkin, A. (2008). Teachers as role models: Teacher character and moral virtues. JOPERD, 79(2): 45 - 49.

Mncube, V., \& Harber, C. (2010). Chronicling educator practices and experiences in the context of democratic schooling and quality education in South Africa. International Journal of Educational Development, 30(6), 614-624. Retrieved November 4, 2011, from http://www.sciencedirect.com.ezproxy.auckland.ac.nz/science/article/pii/S0738059310000222

Narvaez, D. (2001). Nurturing character in the middle school classroom: Introduction to the project and framework. USA: University of Minnesota.

Narvaez, D., \& Lapsley, D. K. (2008). Teaching moral character: Two strategies for teacher education. Teacher Educator, $43: 156$ - 172.

Ozel, A. (2007). The effects of Turkish geography teachers' personality on his teaching experiences. International Journal of Environmental \& Science Education, 2(3): 75 - 78.

Posel, D., Kahn, K., \& Walke, L. (2007).Living with death in a time of AIDS: A rural South African case study. Scandinavian Journal of Public Health, 35(69): 138-146.

Robinson, M. (2003). Teacher education policy in South Africa: The voice of teacher educators. Journal of Education for Teaching, 29(1), $19-34$

Sava, F. A. (2002). Causes and effects of teacher conflict-inducing attitudes towards pupils: A path analysis model. Teacher and Teacher Education, 18: 1007 - 1021.

Seyyed-Hassan, S., Roghayyeh, B., \& Mostafa, A. (2008). Investigating the influence of teachers' behaviour on the students' selfregulation. Quarterly Journal of Educational Innovations, 22: $105-114$.

Stoll, S. K., \& Beller, J. M. (1998). Can character be measured? Journal of Physical Education, Recreation \& Dance, 69(1): 19 - 24.

Thakrar, J., Zinn, D., \& Wolfenden, F. (2009). Harnessing open educational resources to the challenges of teacher education in subSaharan Africa. The International Review of Research in Open and Distance Learning, 10 (4).

U.S. Department of Education (2007). Mobilizing for evidence-based character education. Retrieved 9th September, 2012 from: http://www.ed.gov/programs/charactered/mobilizing.pdf. 